\title{
The Public Relations of Academic Libraries
}

Mr. Heron is librarian, Graduate Reading Room, University of California Library (Los Angeles).

"T TE GRANT, altho' he had much wit, W h'was very shy of using it, as being loth to wear it out ..." wrote Samuel Butler of his favorite knight, Sir Hudibras. It suggests that Butler, who enjoyed the patronage and subsequent neglect of Charles II, felt that this type of modesty was worth some emphasis. Almost three centuries later, here in the age of the singing commercial, it is certainly no less a virtue. It is perhaps remarkable that our modern society, flooded with the highpowered bathos which permeates our media of mass communication, has retained even a little of the versatile knight's tasteful reticence. It is altogether appropriate that a fair share of the ancient art of selfeffacement should be found in our colleges and universities, rich in the best traditions of the past: Blessed are the meek, for they shall inherit the earth.

Modesty is without doubt a virtue which should be preserved as a part of our heritage of learning. It is a genteel quality, and a scholarly one. However, there have been many instances, both ancient and modern, in which the Gown has eschewed the vulgar antics of the Town, and sometimes suffered thereby. College and university people must often recognize in themselves the reticence of a Hudibras, and this applies no less to librarians than to professors. We have no dearth of wit at our disposal if we choose to use it: in our literary stockin-trade are to be found the persuasive techniques of Saint Francis and Friederich Engels, of Gandhi and Hitler, of François Villon and Billy Graham, of Abraham Lincoln and Gerald L. K. Smith.

The art of persuasion is no newer than the art of reticence, although it has developed some techniques which, for better or for worse, make it a more conspicuous part of our twentieth-century culture. Even academic libraries, twice removed, as it were, from the din of the market place, cannot afford to refrain entirely from the competitive devices which characterize our business, our government, our science, and even the administration of higher education.

Public librarians have had to recognize this competition. College and university libraries may be tempted by the illusion that they can rise above the need for active public relations programs because they, unlike public libraries, have what might be termed captive audiences. The very nature of the instruction and research programs of a college or university provides a more specific demand for library service than is to be found in the community served by the public library. If the school's education and research programs are effective, the library will generally have more faculty requests for new books than it can afford to fill. Its reading rooms will often be crowded to capacity, and its reference, circulation, and reserve desks humming with activity. This is not universally true, of course, but it is true in enough cases to prompt the question: 
What do we need of a public relations program? Business is good enough already.

Any librarian who indulges in this type of thinking should ask himself a few more questions: What percentage of your student body uses the library regularly? How well do you satisfy the ones who do? Are you supplying your faculty with all they need? Are all your subordinates performing to your satisfaction? How much are you paying them?

The cold fact is that a well-operated college or university library is just as dependent upon its students and faculty as a public library is dependent upon the citizens of its community. ${ }^{1}$ The academic library has some advantage in the fact that a larger proportion of its users has specific reason for being there, but a captive audience has the prerogative of going to sleep. An academic library should be a wakeful place, the center of activity, able to compete in its own sphere with the many distractions so dear to the undergraduate heart, and able to draw the faculty from their offices and gardens in search of new treasures of their trade.

To be worthy of close and cordial support from the students and professors is the most important objective of the library's program of public relations. Failing this, it descends from being a strong educational instrument to the status of administrative overhead. Librarianship, failing this, becomes little more than custodianship.

The second objective in terms of educational responsibility, but inseparable in terms of cause and effect, is the promotion of financial support. With few exceptions a library gets no more than it can pay for, in books, services, space, or equipment. Its

\footnotetext{
1 "The success of the college library in carrying out its functions is dependent upon the confidence and respect of those it serves," writes Guy $R$. Lyle in The Administration of the College Library, 2d ed.. New York, Wilson, 1949, (p. 483). "Progress can be made only as the record of library achievement is made known."
}

ability to provide books which its faculty and students need, together with a competent and enthusiastic staff to make them available, is generally in direct proportion to the size of its annual budget.

There are other benefits to be derived from the attitude of constructive and continuing self-consciousness which must be the basis for a successful public relations program. A dynamic unity of purpose is good for staff morale. It tends to counteract the anomalous social and institutional position of the library staff, particularly of the junior members, if it is actively integrated into the campus community. It serves to advance the profession of librarianship and to dispel the stereotype which represents its members as glowering guardians of dusty books. It serves to advance the reputation of the school, which will always be judged, particularly by visiting scholars, in terms of its library; it may frequently advance the reputation of the United States in the eyes of foreign scholars, many of whom have visited a number of institutions under State Department auspices, who rightly feel that American librarianship has done much to win us friends abroad.

What, then, is involved in a program of public relations for an academic library? "Public relations" is a phrase used in such a variety of ways that it is somewhat embarrassing to apply it to an academic institution. It has come to be associated with the lucrative business of selling people things they don't need; it has some connotation of cynicism and dishonesty, and a whole family of euphemisms has developed around it-"Public Service," "Public Information," "Customer Services," "Press Relations," "Public Affairs" (this last recently adopted by the publicity department of the mortuary combine around which Evelyn Waugh wrote The Loved One, and others). 
Still it is a logical and comprehensive term, and a twentieth-century institution, applying not only to commercial salesmanship but to the promotion and interpretation of public institutions.

As applied to a college or university library it might be defined as the sum of the library's external relations with students, with faculty, with administrative officers, and with the community at large; and generally in that order of importance, depending on the library's size and circumstances. A public relations program is no more than the articulated realization that the library's effectiveness as an educational institution depends upon its ability to "show readers in what way the library is indispensable to them." 2

The most important impression will be derived from the manner in which the library performs its essential functions of getting books, making them readily available, and answering questions from and about them. This involves the whole library staff and the general administrative efficiency of the library: no fitting subject for this brief essay. Here it must suffice to say that every member of the staff should be kept aware that he or she bears a full share of the responsibility for molding this impression. The critical points in dealing with the majority of the library's constituency will, of course, be the reference and circulation services. Courtesy, conscientiousness, and adaptability are required at reference and loan desks under circumstances which may often be strained. Every effort should be made to encourage these qualities: a good first impression, multiplied a hundred-fold, can make the library a more effective educational instrument. A bad first impression, on the other hand, need not

\footnotetext{
${ }^{2}$ Orr, Robert W., "Public Relations for College and University Libraries," Library Trends, I:124, July,
} 1952. be often repeated to do considerable damage.

The chief librarian's relations with the faculty and administration are very important factors, not only in the provision of the financial support for the library's operation, but because faculty members must occasionally be reminded of the library's usefulness to them and to their students. It will generally be through them that students will discover the library and make constructive criticism of its services. Faculty members themselves can frequently contribute much toward the formation of library policy from their experience in other institutions and from the requirements of their particular disciplines. ${ }^{3}$

The largest number of library users consists of undergraduate students. They are the ones who require the most encouragement in discovering the scholar's affinity for books, but often because of their youth and their numbers they are barred from the bookstack and made to subsist on the slim ration of reserve book reading. The library staff must continuously refrain from treating them with condescension-an attitude which all too often makes them feel that their library is no more than a petty bureaucracy designed to frustrate them. An important part of an academic library's public relations program must be a deliberate sensitivity to the requests and complaints of undergraduates. Although the most important consideration in developing in them a sense of identity with the library is their treatment at public service desks, it is worthwhile to experiment with other means of counteracting their apprehensions. ${ }^{4}$ The publication of a student handbook, a guide to the library aimed primarily at freshmen but valuable to anyone new to the library,

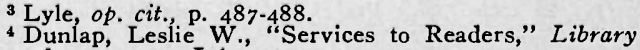
Trends, I : 52.53 , July, 1952.
} 
can be very useful in this regard. It should be an attractive booklet, well organized, concise, and colorful. In its compilation the objectives of brevity and simplicity must eclipse the desire to make it all-inclusive. Attempts at humor should be carefully tested, but good illustrations are to be desired. In addition to the library handbook other guides should be published as they are needed, particularly reference books for which there is a strong general demand.

Some sort of formal instruction in the use of the library should be given, if possible, to every new student. ${ }^{5}$ Although it is not always possible in a large institution, it is desirable that the instruction be by a member of the library staff. Establishing such a program will often require tact and imagination in achieving acceptance from the faculty, because even an hour's lecture during scheduled class time early in the semester may be regarded as an unwarranted interruption of regular courses. It is equally difficult to schedule extra classes in library instruction where attendance is small enough to be effective. There is no denying the value of this sort of program, however, and many colleges and universities have adopted it. The library's instructor should be chosen with care, and must prepare the lectures on the assumption that the subject matter will seem at once esoteric and pedestrian to many of the students, yet must avoid talking down to them. Visual devices and a few examples of the library's wares are often effective in stimulating interest. Several fairly successful attempts have been made at motion pictures on the use of the library, ${ }^{6}$ but in most instances they have been produced for use in particu-

5 Wilson, L. R., and Tauber, M. F., The University Library, Chicago, University of Chicago Press, 1945, p. 394-395.

Liberst-known is the University of Illinois

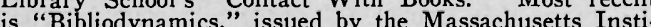
tute of Technology. One of the most dramatic, although not entirely applicable to college library use, is "The not entirely applicable to college library use, is "The
Library of Congress" produced by the OWI in I 944 . lar institutions, and technical difficulties have yet to be overcome in producing a generally usable film.

It is desirable that the library achieve some effective rapprochement with the student body organization (which relationship must unfortunately be renewed, in effect, every year) both to furnish a continuing channel for criticism and suggestions and to promote cooperation with the student newspaper. Good library coverage in the college paper can do a great deal to interest its readers in the library. Conversely, cooperation between the librarian and officers of the student body-or better still between the librarian and a student library committee-makes possible a better understanding of the needs of the majority of the library's users.

In addition to releases to the student paper, any library event of importance should be reported through the college or university public information or press officer to at least the local dailies, and to appropriate professional, scholarly, or news journals.

There are a number of ways in which the library can add to the cultural life of the campus: record concerts, motion pictures, lectures, and seminars can often be given from, or based upon, the library's resources. Although it is not the library's responsibility to initiate this type of activity when some other department is primarily interested, the librarian should be alert for opportunities to provide appropriate services which are not otherwise available.

Not even the largest university libraries are often able to afford the services of a full-time staff artist, but good displays, good signs, and careful planning of the library's decor are a very important part of a public relations program. ${ }^{7}$ It may be possible to

7 Ideas are to be found in such columns as the Wilson Library Bulletin's "Publicity That Worked." Somewhat higher artistic standards are perhaps to be found in art and advertising journals. 
depend upon one of the permanent staff members for design and decoration in the library, or it may be possible to find artistic ability among the student assistants. Amateur sign-painting should be discouraged, even if it is necessary to have work done commercially. In the interests of consistency the library's art work should be under the general direction of one staff member. If no competent artist is available on the staff, it should not be too hard to persuade a member of the art faculty to serve as a permanent advisor. In the preparation of exhibits, of course, faculty members can often make valuable contributions in substance as well as form: it requires a great deal of imagination of the staff member responsible for preparing new exhibits if they are changed frequently enough to be effective.

A college or university library is bound to have a good many visitors. They may be old grads returning to point out to a new generation the spot in the reading room where they tethered the cow the weekend we beat State College 40-o, or they may be visiting scholars come to examine one of the library's particularly good collections. Generally they will more closely approximate the latter category in their interests, and they provide at once an index to the library's excellence and an opportunity to demonstate publicly that it is worthy of being the center of a distinguished educational institution. They will not be so numerous as to interfere with the library's work, and they deserve all the attention which can be spared from normal activities.

The librarian's reports and budget requests to the faculty and administration are a particularly important channel of communication. The library is, or should be, one of the major administrative units of the institution. As such it is responsible for reporting in sufficient detail all of its achievements and requirements. Further it is liable, because of the long span of its development, to be the victim of budgetary procrastination, even neglect. Somewhere up the administrative ladder there is a good chance that the request for library funds will encounter the point of view which sets the value of new football uniforms above the value of books. Even if this hazard is absent the administration will have to make difficult choices between the library and other equally important educational activities. The librarian would be ill-advised, of course, to suggest sacrificing badly needed teaching and research programs to allow the library to buy 19 incunabula per year. However he must remember that the library's ability to perform its assigned function rests directly upon its financial resources. For this reason his reporting and budget justifications must be careful, forceful, and documented in detail. Since the library's function and organization is not comparable to those of any other campus activity, his reporting need not be circumscribed by the standards set by other departments. ${ }^{8}$

The library should if possible publish a bulletin of information, attractive in format and carefully edited. If the staff is small, the primary purpose of this bulletin should be to inform the faculty, administration, and other libraries of recent acquisitions, plans, and achievements. If the staff is large the bulletin acquires the dual function of reporting to the library's constituents and of keeping the staff informed of the library's activities, with whatever additional news is of interest to intramural readers. The very least effort in this direction should be a periodic list of new books, to which

$8 \mathrm{Wilson}$ and Tauber, $o p$. cit., p. $80-83$. The annual reports of the Library of Congress, the University of California, Princeton and Yale Universities provide an interesting variety of styles and sizes. 
news notes can cautiously be added if the demand warrants. There is some question as to the advisability of distributing such a library bulletin beyond the gates of the campus, except to other libraries and library schools. As a general rule it should be sent only to those faculty members and offcampus friends who specifically ask for it: it is difficult and expensive to publish a bulletin whose contents are of wide enough general interest to staff, faculty, and offcampus readers to be successful. Aside from the Library of Congress Information Bulletin there are few publications designed for all three groups of readers which can be so regarded. The alternative device is a publication of such a journal as the Princeton University Library Chronicle, the Yale University Library Gazette, the Journal of the Rutgers University Library, or the less pretentious Mercurius Redivivus and Bancroftiana of the University of California's Clark and Bancroft Libraries.

These periodicals are designed to attract interest in the libraries' collections on the part of potential Friends of the Library. A considerable number of academic libraries have developed Friends organizations to facilitate and encourage private gifts to the libraries to supplement normal operating funds. With such gifts it is often possible to increase the library's effectiveness not only through valuable additions to the collection, but through the establishment of funds for publication of research performed in the library. Such publication and the purchase of expensive rarities are frequently important to the library's development but difficult to justify in the normal budgeting process.

There are many other specific devices through which college and university librarians can increase the library-consciousness of their supporters and constituents. There are few academic librarians who have either the temperament or the opportunity to emulate the brilliant "culture huckster" of Louisville, simply because of the essential differences between the communities they serve. It is possible, however, within the framework of the interests and requirements of faculty and students to increase the centripetal force of the academic library in a number of effective and appropriate ways. For its librarian and his staff this means speaking up in the library's behalf, seeing to it that faculty, students, and friends do the same, and that the first impressions of the library speak for themselves.

Remembering always that the basic requirement for good public relations for the academic library is the quiet and efficient manner in which it provides people with the books and information they want, a college or university librarian should also consider that he is responsible to his staff, his faculty, and his students for meeting and matching the intellectual, social, and financial competition which he cannot avoid, and which is quite capable of impairing the effectiveness of his service to them. It is a responsibility which cannot be discharged with reticence.

\section{AV Institute}

The Audio-Visual Board and the Audio Visual Round Table are co-sponsoring an AV Institute at the Warwick Hotel in Philadelphia, July 2 and 3. Dr. Louis Shores, Chairman of the ACRL Committee on Audio-Visual Work is planning a half-day program on the use of audio visual materials in academic teaching and research. Ir a Peskind will act as coordinator, John Moriarty as chairman of this program. During the two-day meeting there will be sessions on recordings, television, cooperative film services, and other subjects.

The Audio Visual Round Table, organized a year ago, provides an opportunity for all ALA members interested in audio visual services to meet and discuss common concerns. If you are interested in membership write to Virginia Beard, Cleveland Public Library. Annual dues for the Round Table are $\$$ r.oo. 